\title{
Modeling the sensitivity of CERES-Rice model: An experience of Nepal
}

\author{
A Lamsal $^{1}$, LP Amgai $^{2}$ and A Giri ${ }^{3}$ \\ ${ }^{1}$ Kansas State University, USA, ${ }^{2}$ IAAS, Rampur, Nepal, ${ }^{3}$ University of Toledo, USA
}

\begin{abstract}
The experiment was conducted with four levels of nitrogen $(40,80,120$ and $160 \mathrm{~kg} / \mathrm{ha})$ and 3 different cultivars (Prithivi hybrid), Masuli (HYV) and Sunaulo Sugandha (Aromatic).RMSE value $(747.35 \mathrm{~kg} / \mathrm{ha}, 1.106$ days, 2.58 days and $0.004 \mathrm{~kg} / \mathrm{ha})$ and D-stat value $(0.793,0.99,0.99$ and 0.633 ) for grain yield, anthesis days, maturity days, and individual grain weight respectively. The objective of this study was to identify whether CSM-CERES-Rice model can be used in Nepalese condition and to evaluate the sensitivity of model with impact of climate change on rice production. Eight different climate scenarios were built by perturbing maximum and minimum temperature $( \pm$ $\left.4^{0} \mathrm{C}\right), \mathrm{CO}_{2}( \pm 20 \mathrm{ppm})$, solar radiation $\left( \pm 1 \mathrm{MJ} / \mathrm{m}^{2} /\right.$ day $)$ using interactive sensitivity analysis mode in DSSAT. Among the scenario evaluated, temperature $\left( \pm 4^{0} \mathrm{C}\right), \mathrm{CO}_{2}$ concentration $(+20 \mathrm{ppm})$ with change in solar radiation $\left( \pm 1 \mathrm{MJ} \mathrm{m}^{-2}\right.$ day-1) resulted maximum increase in yield (by 62,41 and $42 \%$ ) under decreasing climatic scenarios and sharp decline in yield (by 80, 46 and 40\%) was observed under increasing climate change scenarios, in Prithivi, Masuli and Sunaulo Sugandha cultivars respectively.Not surprisingly, increasing yield by $(48,25$ and $27 \%)$ and decrease in yield by(77, 41 and 34$)$ by perturbing only maximum and minimum temperature by $( \pm 4)$ shows that the temperature is most sensitive for yield potentiality of cultivars than other. CERES-Riceversion 4.0 was well calibrated in Chitwan Nepal condition. The model applications show that model could be a tool for precision decision-making. There was variation in yield in response to the change in climatic scenario in the study. RMSE value ( $747.4 \mathrm{~kg} / \mathrm{ha}, 1.11$ days, and 2.58 days), and d-stat (0.79, 0.99 and 0.99 ) for grain yield, anthesis, and maturity days confirm the possibility of CERESRiceuse in Nepalese agriculture. The finding showed that there was sharp decrease in rice yield due to change in temperature, $\mathrm{CO}_{2}$ and solar radiation. Climatic scenario developed by CERES-Rice model in sensitivity analysis resulted yield reduction up to $80 \%$. Among the cultivar, hybrid rice shows more vulnerability with climate change. Decrease in yield were mainly associated with lowering growth duration along with increasing temperature, where as there is very less counter effect of increasing carbon dioxide concentration and solar radiation.
\end{abstract}

Keywords : CERES-Rice, sensitivity, yield, and cultivars

\section{Introduction}

Rice (Oryza sativa L.) is one of the most important food crops of Asia and three fifth home of the humanity(Auffhammer, et al., 2012). In Nepal, rice ranks the first on the basis of area (1.48 million ha.)and production (4.02 million ton) with theproductivity of $2.71 \mathrm{t} / \mathrm{ha}$, which contributes more than $20 \%$ agriculture gross domestic product (AGDP) (MOAC, 2010/11). Variation of extreme weather pattern rise in temperature, varied precipitation resulted declining production of crop in major region of Asia (Tragolraam et al 2011). Despite of rapid advancement in agriculture sector, weather is still key factor impacting crop productivity and declining yield (Sapkota, et al., 2010). Last 32 years of climatic data of Nepal showed that temperature has been increased by $1.8^{\circ} \mathrm{C}$ with average rise of 
$0.06^{\circ} \mathrm{C}$ per year along with high intensities of rainfall and less number of rainy days (Malla, 2009) where as computer simulation indicate that average global temperature will rise by $1.1-6.4^{\circ} \mathrm{C}$ by end of the $21^{\text {st }}$ century. Concerning food security of underdeveloped country like Nepal, negative impact of climate change on rice yield can be a serious issue in near future. It is, therefore, most essential to quantify possible impact of climate change and adopt mitigation measures to solve the problem of food scarcity.

Impact of climate change on agriculture production varies depending on varying region(Vucetic, 2011) which enable researcher to study their impact at local, regional and global level. The decision support system for agro technology transfer (DSSAT) developed by the International Benchmark Systems Network for Agro-technology Transfer (IBSNAT) embedded with CERES-Rice is a process based simulation model (Jones et al 2003) which enables user to quantify variability of crop performance with response to variability in seasonal weather condition and long term impact of climate change (Timsina, et al., 2010). CERES-Rice has been widely used all over the world (Aggarwal, et al., 2002; Lal, et al., 1998; Mahmood, 1998; Rosenzweig, et al., 1994; Yao, et al., 2007) for investigating climate change impact on rice production. Having variety-specific in nature (Jones, et al., 2003), the CERES-Rice model perform based on individual genetic coefficient which enable model to perform more precisely.

There are various method evolved to evaluate the impact of uncertainty in model input. Here we select the most important tools; sensitivity analysis (Saltelli, 2002). Very few sensitivity analysis method have been used for crop model (DeJonge, et al., 2012). Noticeable studies have been carried out (Aggarwal, et al., 2002; Pathak, et al., 2004) and evaluated the sensitivity of rice model with respect to weather parameter.The objective of this study was to evaluate the Ceres-rice model in Nepalese condition and to quantify the impact of climate change on growth and development of hybrid and HYV's variety of rice. In addition sensitivity of Ceres-rice yield with perturbing climatic data set (Temperature, $\mathrm{CO}_{2}$, solar radiation and weather years).

\section{Material and methods}

The study was conducted with data from experimental site located in central Nepal, at the Institute of Agriculture and animal science (IAAS) Chitwan, Nepal $\left(27^{\circ} 37^{\prime} \mathrm{N}\right.$ and $84^{\circ} 25^{\prime} \mathrm{E}, 256$ above sea level). It is climatically characterized as humid sub tropical with medium rainfall resembling the foot-hill and inner-Terai climate. The site annually receives about $2000 \mathrm{~mm}$ of rain, about $80 \%$ of which occurs from mid June to mid September. Humidity starts rising up from May (average 50\%) and reaches to its extreme (100\%) in December and January. Daily rainfall, maximum minimum temperature, sunshine hours and relative humidity ware collected as required by model. Sun shine hours were converted in to the solar radiation with the wgenbased weather generator (richardson, et al., 1984), included in weatherman (tools of DSSAT).

$$
R_{s}=R_{a}\left(a+b\left(\frac{n}{N}\right)\right.
$$

Where, $\mathrm{R}_{\mathrm{s}}=$ Total radiation, $\mathrm{R}_{\mathrm{a}}=$ Extra terrestrial radiation, $\mathrm{a} \& \mathrm{~b}=$ Angstrom Coefficient and approximate to latitude, $\mathrm{n}=$ Sunshine hours and $\mathrm{N}=$ Day length 


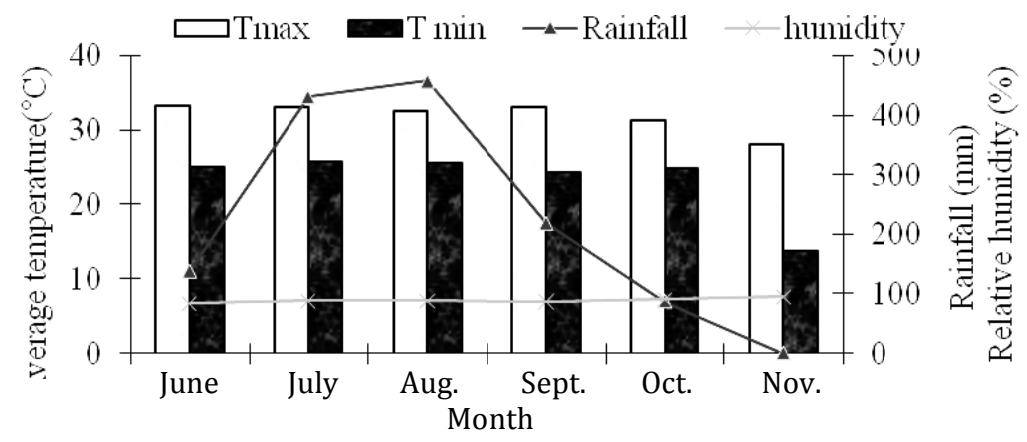

Fig 1. Weather data of experimental location for crop growing period at Rampur, chitwan, Nepal during 2008

\section{Soil analysis}

As of DSSAT requirement (jones, et al., 2003), soil samples from vertical profile up to 100 $\mathrm{cm}$ were taken for physical and soil profile about a week before transplanting. Table 1 shows the detail characteristics of the soil profile of the experimental site. Soil at the experimental site was sandy loam. Four levels of nitrogen (40,80, 120 and $160 \mathrm{n} \mathrm{kg} / \mathrm{ha}$ ) with different cultivar (hybrid- Prithivi, aromatic-Sunaulo Sugandha (SS) and inbred- Mansuli) were used. Experiment was conducted considering two factorial randomized complete block design $(R C B D)$.

Table 1. Soil characteristics of experimental site during 2008 at IAAS, Rampur, Chitwan, Nepal

\begin{tabular}{cccccccccccccc}
\hline$(C M)$ & $D U L$ & $D L L$ & $\begin{array}{c}B / C M \\
G / C\end{array}$ & $\begin{array}{c}S A T \\
(C M)\end{array}$ & $\mathrm{pH}$ & $\begin{array}{c}\mathrm{NH}_{4}^{+} \\
(\%)\end{array}$ & $\begin{array}{c}\mathrm{NO}_{3}{ }^{-} \\
(\%)\end{array}$ & $\begin{array}{c}\mathrm{Tot} \\
\mathrm{N} \\
(\%)\end{array}$ & $\begin{array}{c}\mathrm{Pg}_{2} \mathrm{O}_{5} \\
\mathrm{Kg}^{-}\end{array}$ & $\begin{array}{c}\mathrm{K}_{2} \mathrm{O} \\
\mathrm{Kg} \\
\mathrm{ha}^{-1}\end{array}$ & $\begin{array}{c}\mathrm{OC} \\
(\%)\end{array}$ & $\begin{array}{c}\text { Silt } \\
\%\end{array}$ & $\begin{array}{c}\mathrm{Clay} \\
\%\end{array}$ \\
\hline $0-20$ & 0.188 & 0.104 & 1.47 & 42.6 & 6.8 & 0.0252 & 0.0084 & 0.14 & 37 & 67 & 1.58 & 5 & 7 \\
$20-40$ & 0.207 & 0.105 & 1.50 & 43.7 & 6.8 & 0.0248 & 0.0087 & 0.11 & 27 & 24 & 1.26 & 17 & 9 \\
$40-60$ & 0.154 & 0.075 & 1.43 & 45.6 & 6.7 & 0.0248 & 0.0082 & 0.05 & 15 & 86 & 0.53 & 15 & 7 \\
$60-80$ & 0.142 & 0.077 & 1.42 & 46.2 & 6.6 & 0.0248 & 0.0087 & 0.02 & 15 & 34 & 0.23 & 11 & 9 \\
$80-100$ & 0.100 & 0.047 & 1.47 & 46.68 & 7.0 & 0.0252 & 0.0084 & 0.02 & 37 & 34 & 0.22 & 7 & 3 \\
\hline
\end{tabular}

\section{CSM CERES Rice model}

Crop simulation model was build with aiming to simulate crop growth, development and yield along with change in soil water, carbon and nitrogen balance under the cropping system (Jones, et al., 2003) CERES- Rice is a individual sub module embedded with DSSAT (Decision support system for agro-Transfer technology) that simulates phenology, daily growth and partitioning, plant nitrogen and carbon demands, senescence of plant material, etc. CERES-Rice model embedded with DSSAT v 4 shell (Jones, et al., 2003) is widely used model for various purposes, with major focus on climate change impact assessment (Rosenzweig, et al., 1994). CERES-Rice simulate yield (Evans, 1993; Ritchie, et al., 1998) and biomass based on equation as follows.

$$
Y=I_{H \eta R} \sum_{i=1}^{N}\left(Q_{d P A R i} R_{\eta} f_{i} \Delta_{\mathrm{Ri}}\right)
$$


Where

$\mathrm{Y}=$ grain yield as dry matter in $\mathrm{g}^{-2} ; \mathrm{I}_{\mathrm{H}}=$ harvest index (grain as a fraction of the aboveground biomass), $\eta R=$ the value of the RUE in $\mathrm{g} \mathrm{MJ}^{-2} ; Q_{d P A R i}=$ average daily total of incident PAR for a given month (i) in $\mathrm{MJm}^{-2} f_{i}=$ fraction of PAR intercepted; $R_{\eta}=$ number of days of radiation interception; $\Delta_{\mathrm{Ri}}=$ fraction of the maximum RUE depending on crop performance, in $\mathrm{gMJ}^{-2} ; \mathrm{N}$ is the number of months. Similarly total biomass production (Ritchie, et al., 1998) will accompanied from average growth rate $\left(\mathrm{B}_{\mathrm{T}}\right)$ and growth duration $(\mathrm{d})$

$$
B_{T}=g \times d
$$

Where growth of plant determined as

$$
C A R B O=R U E * P A R *[1-\exp (-K * L A I)]
$$

Where $\mathrm{CARBO}=$ net photosynthesis, $\mathrm{RUE}=$ radiation use efficiency, $\mathrm{LAI}=$ leaf area index and $\mathrm{k}=$ extension coefficient. Value for RUE assumed as $2.95 \mathrm{gMJ}^{-1}$, where temperature range from $14-32^{\circ} \mathrm{C}$

\section{Result and discussion}

\section{Model calibration and evaluation}

Calibration was done with the independent data sets of three rice cultivars viz. Prithivi and Sunaulo Sugandha with $160 \mathrm{Kg} \mathrm{N} / \mathrm{ha}$ and Masuli with $120 \mathrm{Kg} \mathrm{N} / \mathrm{ha}$ (Table 2) for different genetic coefficient which characterize the rice performance. Accuracy in simulation of yield, phenology and growth requires the accurate genetic coefficient (Quiring, et al., 2008). These coefficients were adjusted until there was a close match between the observed and simulated dates of anthesis, physiological maturity and grain yield (Table 2)

The performance CERES-Rice was tested and evaluated using the above-determined coefficient for rest of the varieties with their respective fertilizer other than calibrated one. Two statistics were used to evaluate the model performances. (i) Root Mean Square Error (RMSE) and (ii) d stat index (Willmott, 1982) inch is illustrated in equation (1 \& 2).Willmott (1982) stated that the d stat index value should approach unity and the RMSEs approach zero for good performance of the model.

\begin{tabular}{|c|c|c|c|c|}
\hline \multicolumn{2}{|c|}{ Genetic coefficient } & \multirow{2}{*}{$\begin{array}{l}\text { Prithivi } \\
670\end{array}$} & \multirow{2}{*}{$\begin{array}{l}\text { Masuli } \\
840.7\end{array}$} & \multirow{2}{*}{$\frac{\text { SS }}{891.9}$} \\
\hline P1 & Basic vegetative phase of the plant. & & & \\
\hline $\mathrm{P} 20$ & $\begin{array}{l}\text { Critical photoperiod or the longest day length (in hours) at } \\
\text { which the development occurs at a maximum rate }\end{array}$ & 50.7 & 186.1 & 232 \\
\hline $\mathrm{P} 2 \mathrm{R}$ & $\begin{array}{l}\text { Extent to which phasic development leading to panicle } \\
\text { initiation is delayed }\end{array}$ & 330 & 251 & 220 \\
\hline P5 & Time period in GDD ${ }^{0} \mathrm{C}$ ) from beginning of grain filling & 10.2 & 10.8 & 10.9 \\
\hline G1 & Potential spikelet number coefficient & 69.9 & 42.4 & 42.2 \\
\hline G2 & Single grain weight (g) under ideal growing conditions. & 0.295 & 0.020 & 0.242 \\
\hline G3 & Tillering coefficient & 0.97 & 1.0 & 1.00 \\
\hline G4 & Temperature tolerance coefficient. & 1.13 & 1.0 & 1.00 \\
\hline
\end{tabular}

Table 2. Calibrated genetic coefficient and their values 


\section{a. Root Mean Square Error}

$$
R M S E=\left\lceil\sum_{i=1}^{n} \frac{\left(P_{i}-O_{i}\right)^{2}}{n}\right\rceil^{0.5}
$$

\section{b. D-stat index}

$$
d=\frac{\sum_{i=1}^{n}\left(P_{i}-O_{i}\right)^{2}}{\sum\left(\left|P_{i}-O_{\text {iavg }}\right|\right)+\left(O_{i}-O_{\text {iavg }}\right)^{2}}
$$

Where, $O_{i}=$ Observed Value, $P_{i}=$, Predicted Value, $O_{\text {iavg }}=$ average of the obeserved value, $\mathrm{n}=$ number of observation

Observation on anthesis, physiological maturity days, grain yield, and unit grain weight were used for the model validation (Fig 2). Predicted grain yield was well agreed with observed yield $(\mathrm{RMSE}=747.4 \mathrm{~kg} / \mathrm{ha}, \mathrm{d}$-stat $=0.79)$. Similarly, close agreement was observed between observed and simulated anthesis date $(\mathrm{RMSE}=1.11 \mathrm{~d}$-Stat $=0.99)$ and physiological maturity dates $(\mathrm{RMSE}=$ 2.58 days, $\mathrm{d}$-stat $=0.99$ ). Also fairly satisfactory agreement was found with the unit grain weight $(\mathrm{RMSE}=0.004 \mathrm{mg}, \mathrm{d}$-stat $=0.63)$. Thus these validation results showed that the CERES-Rice model could be safely used as a tool for simulation of different agronomic and climate change parameter.
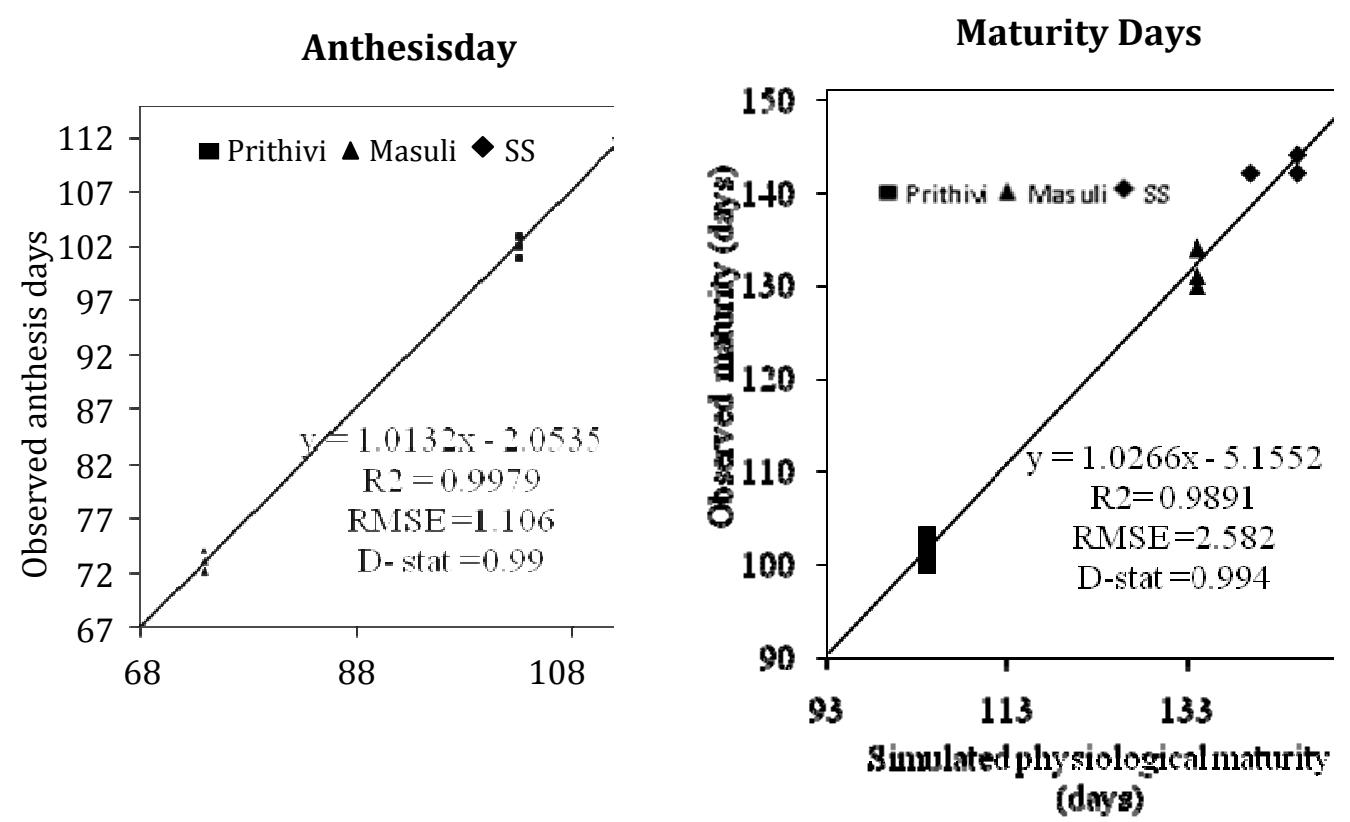

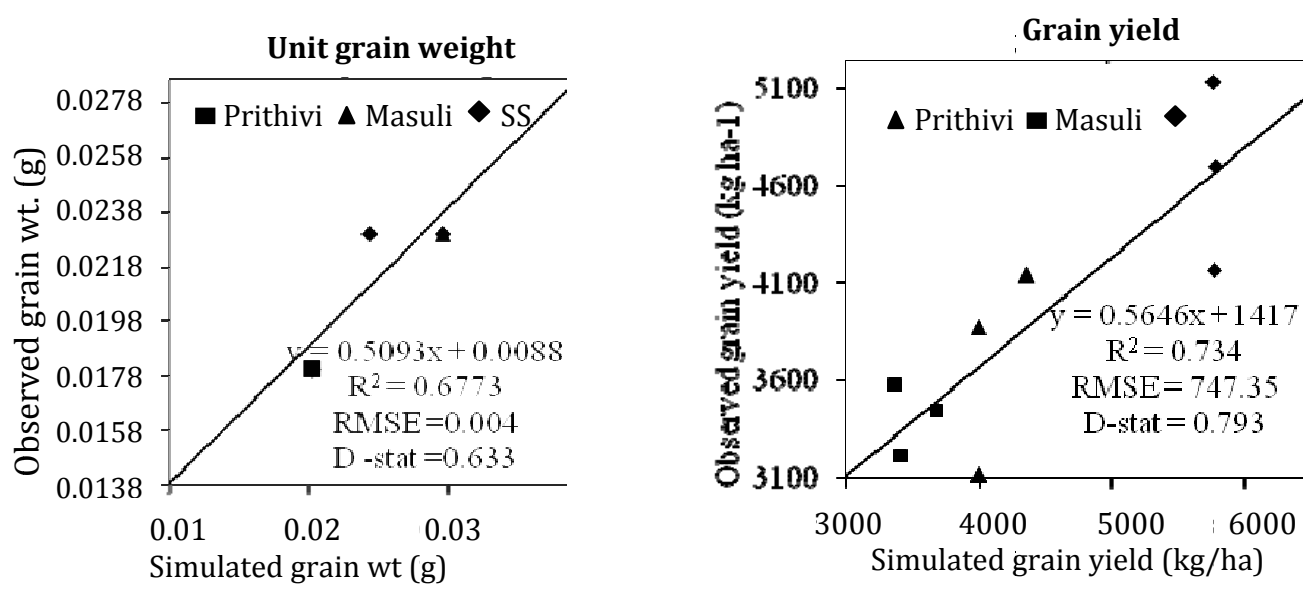

Fig 2. simulated and observed Anthesis days (a), maturity days (b), Unit grain weight (c), and Grain yield (d)

\section{Sensitivity analysis}

Sensitivity analysis is the study of how the variation in the output of a model can be apportioned to different sources perturbing input (Saltelli, 2002). Sensitivity of CERES-Rice was made using systematic changes in Weather years, Maximum and minimum temperature, $\mathrm{Co}_{2}$ concentration and solar radiation.

\section{Sensitivity to weather years}

CERES-Rice was run for the standard treatment using 4 years of weather data (2005-2008) and found sensitive (Fig. 4 and Table 3). Hybrid cultivar Prithivi found more sensitive with change in weather years with reducing yield by 17 and $20 \%$ in year 2007 and 2005 (Fig 4). In addition, year 2007 showed the 12\% lowered yield from HYV's Masuli and Sunaulo Sugandha (Fig 4). Lower yield of the hybrid variety was due to the lower spikelet fertilization rate with high temperature. Lower the availability of solar radiation and high rainfall rate during critical stages (Buan, et al., 1996) and high temperature with scanty rainfall (Amien, et al., 1996) leading to lower yield.

Table 3. Sensitivity of simulated yield and phenology of rice cultivars to weather years

\begin{tabular}{ccccc}
\hline Cultivars & Weather years & $\begin{array}{c}\text { Simulated yield } \\
\left(\mathrm{kg} \mathrm{ha}^{-1}\right)\end{array}$ & Anthesis (days) & $\begin{array}{c}\text { Maturity } \\
\text { (days) }\end{array}$ \\
\hline Prithivi & $2008^{\mathrm{a}}$ & 5754 & 74 & 104 \\
& 2007 & 4759 & 75 & 105 \\
& 2006 & 5679 & 75 & 104 \\
Masuli & 2005 & 4629 & 75 & 103 \\
& $2008^{\mathrm{a}}$ & 3892 & 103 & 134 \\
& 2007 & 3420 & 102 & 132 \\
& 2006 & 3530 & 99 & 133 \\
\hline
\end{tabular}


Agronomy Journal of Nepal (Agron JN) Vol. 3. 2013

\begin{tabular}{ccccc}
\hline Sunaulo & $2008^{\mathrm{a}}$ & 4468 & 112 & 145 \\
Sugandha & 2007 & 3939 & 111 & 142 \\
& 2006 & 4098 & 108 & 137 \\
& 2005 & 4208 & 110 & 143 \\
\hline
\end{tabular}

${ }^{\mathrm{a}}$ Standard years
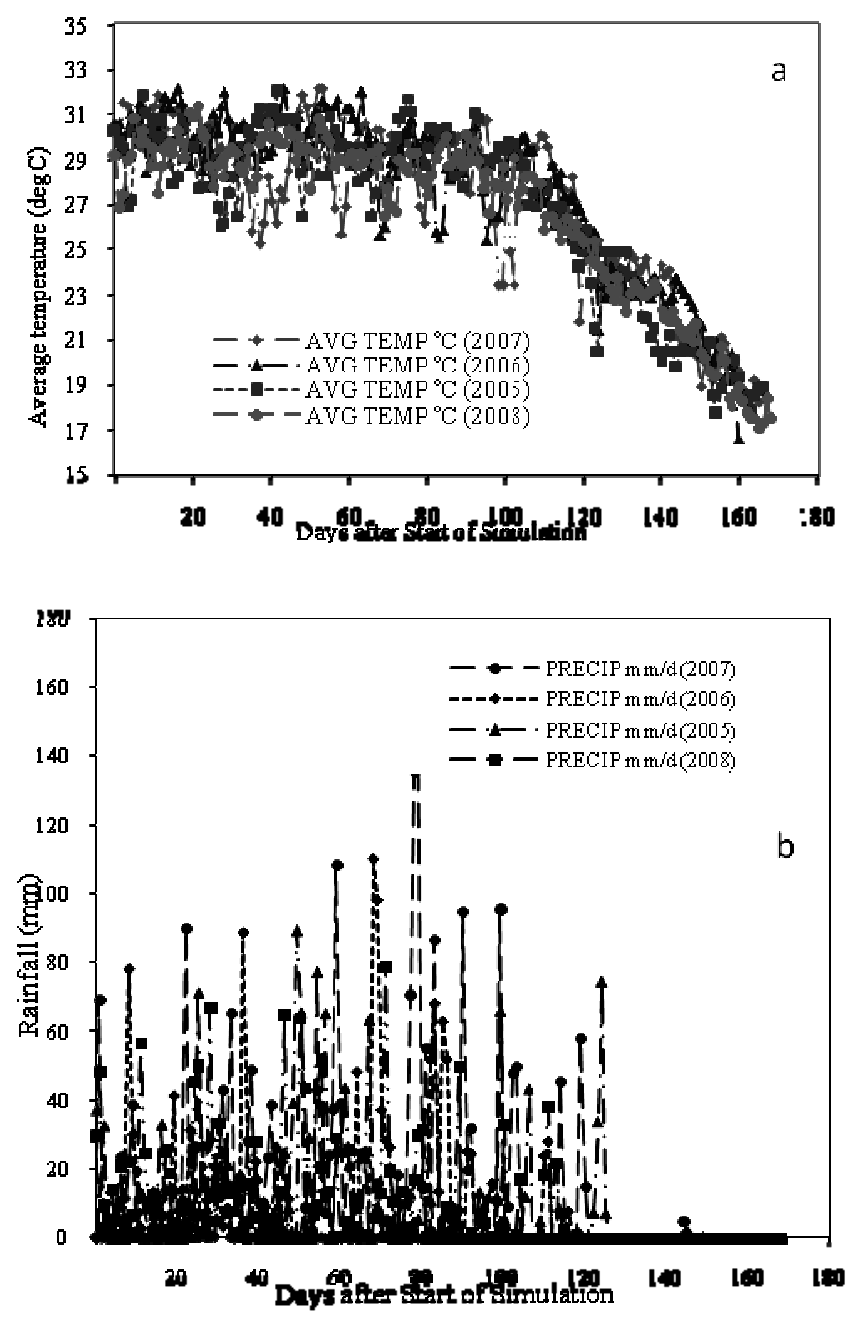


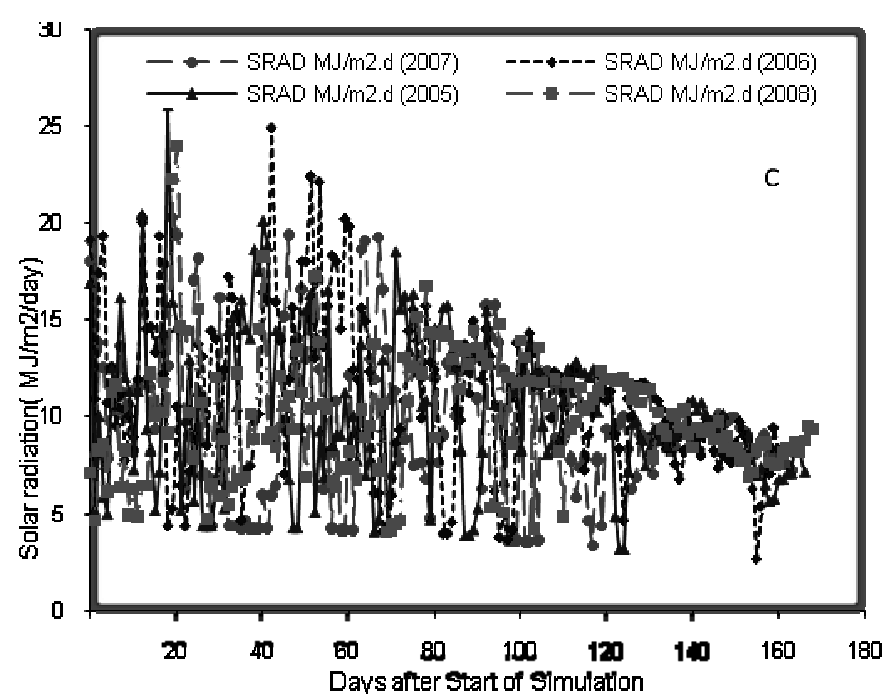

Fig 3. Daily temperature (a), rainfall (b), and solar radiation $\left(\mathrm{MJ} / \mathrm{m}^{2} /\right.$ day) during rice season

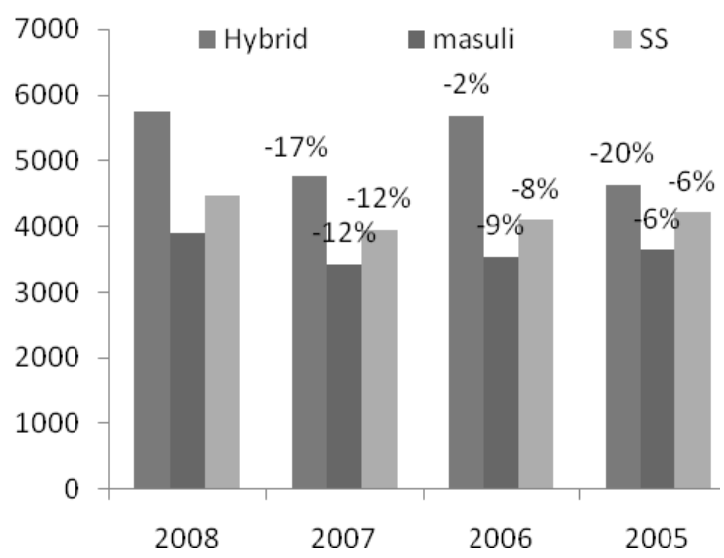

Fig 4. Percentage change in yield in response to different weather years

\section{Sensitivity to daily weather series}

As we already discussed, ambiguities exist in perturbing the different climate years. Furthermorequestion arise how the model is sensitive to change in daily weather pattern. To suggest the answer, various climatic scenarios were assumed to perform sensitivity analysis. Scenarios were developed with perturbing maximum and minimum temperature, solar radiation and carbon dioxide concentration. Details of the scenarios are presented in Table 4. 
Table 4. Description of climatic scenario used for sensitivity analysis

\begin{tabular}{|c|c|c|c|c|c|c|c|c|c|}
\hline Scenario & \multicolumn{9}{|c|}{ Description } \\
\hline A1 & \multicolumn{9}{|c|}{$\operatorname{Tmax}+4^{\circ} \mathrm{C}, \mathrm{Tmin}+4^{\circ} \mathrm{C}$} \\
\hline A2 & \multicolumn{9}{|c|}{$\mathrm{Tmax}-4^{\circ} \mathrm{C}, \mathrm{Tmin}-4^{\circ} \mathrm{C}$} \\
\hline A3 & \multicolumn{9}{|c|}{$\operatorname{Tmax}+4^{\circ} \mathrm{C}, \mathrm{Tmin}+4^{\circ} \mathrm{C}$ and $\mathrm{CO}_{2}+20 \mathrm{ppm}$} \\
\hline A4 & \multicolumn{9}{|c|}{$\operatorname{Tmax}-4^{\circ} \mathrm{C}$, Tmin $-4^{\circ} \mathrm{C}$ and $\mathrm{CO}_{2}+20 \mathrm{ppm}$} \\
\hline A5 & \multicolumn{9}{|c|}{$\operatorname{Tmax}+4^{\circ} \mathrm{C}, \mathrm{Tmin}+4^{\circ} \mathrm{C}$ and $\mathrm{CO}_{2}+20 \mathrm{ppm}$ and SRAD $+1 \mathrm{MJm}^{-2} \mathrm{day}^{-1}$} \\
\hline \multirow[t]{3}{*}{ Varieties } & \multirow{3}{*}{$\begin{array}{l}\text { Standard } \\
\text { (Days) }\end{array}$} & \multicolumn{8}{|c|}{ Scenarios } \\
\hline & & \multicolumn{8}{|c|}{ Growth duration (days) } \\
\hline & & A1 & $\mathrm{A} 2$ & A3 & A4 & A5 & A6 & A7 & A8 \\
\hline Prithivi* & 104 & 96 & 139 & 139 & 96 & 139 & 96 & 139 & 139 \\
\hline Masuli* & 134 & 111 & 212 & 212 & 111 & 212 & 111 & 212 & 212 \\
\hline \multirow[t]{2}{*}{$\mathrm{SS}^{*}$} & 145 & 117 & 226 & 226 & 117 & 226 & 117 & 226 & 226 \\
\hline & $\begin{array}{l}\text { Yield } \\
(\mathrm{kg} / \mathrm{ha})\end{array}$ & \multicolumn{8}{|c|}{ Grain yield (kg/ha) } \\
\hline Prithivi* & 5754 & 1320 & 8533 & 1360 & 8686 & 1548 & 1177 & 9342 & 7976 \\
\hline Masuli* & 3892 & 2310 & 4895 & 2365 & 5144 & 2613 & 2104 & 5486 & 4624 \\
\hline SS* & 4468 & 2928 & 5684 & 2994 & 6027 & 3294 & 2686 & 6385 & 5278 \\
\hline A6 & Tmax & $\mathrm{C}, \mathrm{Tn}$ & $+4^{\circ} \mathrm{C}$ ar & $\overline{\mathrm{CO}_{2}+}$ & $\overline{p m m ~ a n}$ & $\overline{\mathrm{RAD}}$ & $\overline{\mathrm{AJm}^{-2} \mathrm{~d}}$ & & \\
\hline A7 & Tmax & $\mathrm{C}, \mathrm{Tm}$ & $4^{\circ} \mathrm{C}$ an & $\mathrm{CO}_{2}+2$ & $\mathrm{pm}$ anc & $\mathrm{RAD}+$ & $4 \mathrm{Jm}^{-2} \mathrm{~d}$ & & \\
\hline A8 & $\operatorname{Tmax}$ & $\mathrm{C}, \mathrm{Tm}$ & $4^{\circ} \mathrm{C}$ an & 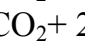 & pm anc & RAD - & $\mathrm{Jm}^{-2}$ & & \\
\hline
\end{tabular}

What about $-20 \mathrm{ppm} \mathrm{CO}_{2}$ ?

Table 5. Simulated rice growth duration (days) and grain yield (kg/ha) with changes in temperature, solar radiation and $\mathrm{CO}_{2}$ concentration

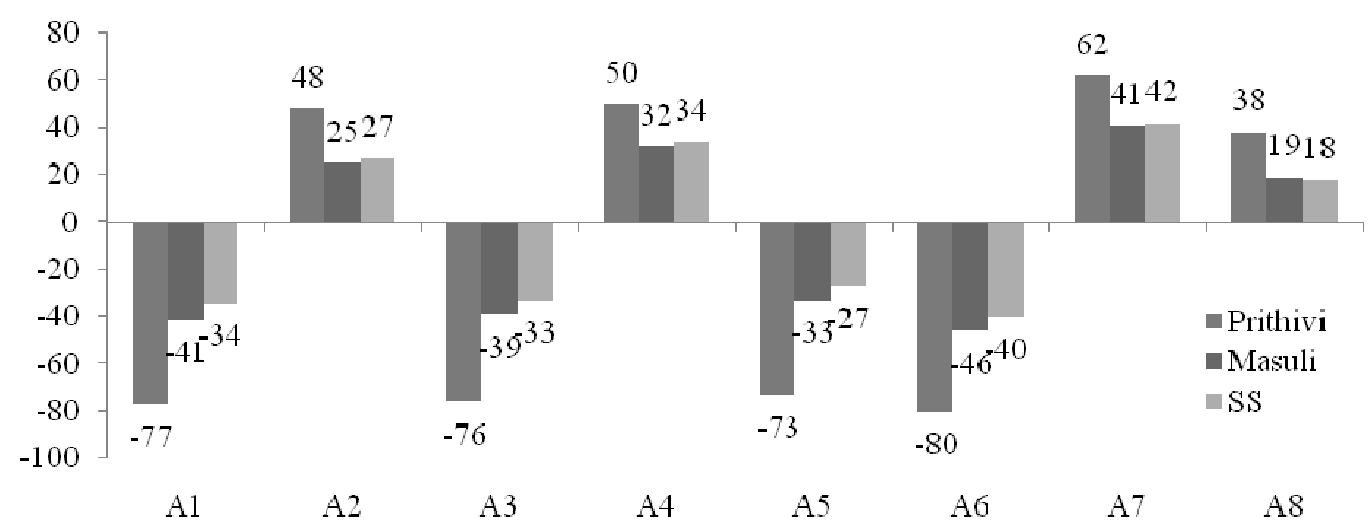

Fig 5. Percentage change in grain yield with respect to various climatic scenarios 
Result clearly indicates that maximum and minimum temperatures are key responsible to determine the yield. Increasing temperature alone by $4^{\circ} \mathrm{C}$ clearly shows drastic reduction of yield up to 34 to $77 \%$ from HYV's and hybrid rice. Decreasing temperature was found to increase yield up to 27 and $48 \%$ (for the same variety)-optional. Furthermore, result showed that the decreasing scenarios of maximum and minimum temperature by $4^{\circ} \mathrm{C}$ along with increasing $\mathrm{CO}_{2}$ concentration and solar radiation by $20 \mathrm{ppm}$ and $1 \mathrm{MJ} /$ day $/ \mathrm{m}^{2}$ results in increased grain yield by 62,41 and $42 \%$ from Prithivi, Masuli and Sunaulo Sugandha. In most site of china, Jin, et al. (1995) observed that the direct effects of increased $\mathrm{CO}_{2}$ concentration compensate the negative effectsof increased temperature on rainfed rice. In contrast, maximum reduction in yield (80, 46 and $40 \%$ )was simulated from the scenario of increasing temperature by $4^{\circ} \mathrm{C}$ and decreasing solar radiation $(1$ $\mathrm{MJ} / \mathrm{day} / \mathrm{m}^{2}$ ). The decline in rice yield in association with increasing temperature were also noticed in India(Aggarwal, et al., 2002; Saseendran, et al., 2000);(Seino, 1995); South Asia (Aggarwal, et al., 2002); Philippines (Peng, et al., 2004). Among the cultivars, hybrid rice seems more sensitive to climatic factors than others.

The solar radiation response was related to the amount of incident radiation and the fraction of radiation intercepted by the crop. Takuya, et al. (1999) reported that insufficient grain filling of hybrid rice was due to shortage of solar radiation which led to the abnormal physio-chemical properties. Light stress was found to decrease total biomass, yield and yield components. The reduction in the ultimate grain yield was due to increased number of ill-filled spikelets (Vijayalakshmi, et al., 1991). However, higher temperatures generally decrease yield by speeding up the development of a plant so that it matures sooner; they often also exacerbate stress on water resources that are essential for crop growth.

Fig 5 and 6 showed that decreased temperature accompanied with increment in $\mathrm{CO}_{2}$ concentration and solar radiation resulted in longer crop duration and higher yield. Similar result was observed by (Karim, et al., 1994). In general, higher $\mathrm{CO}_{2}$ levels in the atmosphere, increase growth and yield, mainly due to their reduced stomatal openings, thereby reducing transpiration per unit leaf area (Peart, et al., 1989) and enhancing photosynthesis effect (Hendrey, et al., 1994).

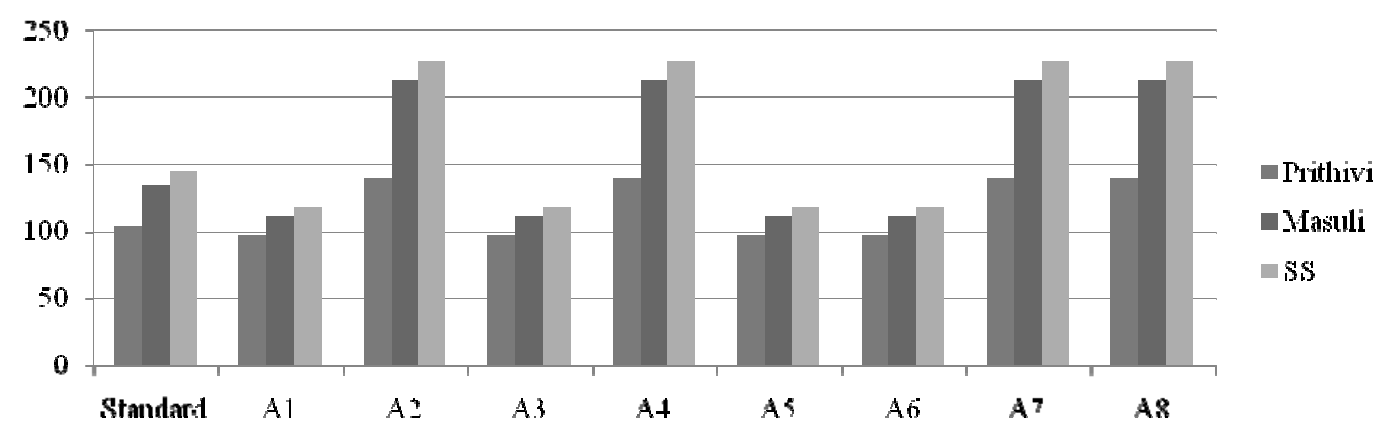

Fig 6. Simulated growth duration with respect to various climatic scenarios 


\section{References}

Auffhammer M, V Ramanathan and J Vincent. 2012. Climate change, the monsoon, and rice yield in india. Climatic Change. 111.411-424.

Sapkota S, MN Paudel, NS Thakur, MB Nepali and R Neupane. 2010. Effect of climate change on rice production. A case of six vdcs in jumla district. Nepal J of Sci. and Tech.11.57-62.

Malla G. 2009. Climate change and its impact on nepalese agriculture. J of Agric. and Env.9.62-71.

Vucetic V. 2011. Modelling of maize production in croatia. Present and future climate. J of Agric. Sci.149.145-157.

Timsina J and E Humphreys. 2010. Application of ceres-rice and ceres-wheat in research, policy and climate change studies in asia. A review. Int. J of Agric. Res.5.587-610.

Aggarwal PK and R Mall. 2002. Climate change and rice yields in diverse agro-environments of india. Ii. Effect of uncertainties in scenarios and crop models on impact assessment. Clim. Chnge. 52.331-343.

Lal M, KK Singh, LS Rathore, G Srinivasan and SA Saseendran. 1998. Vulnerability of rice and wheat yields in nw india to future changes in climate. Agricultural and Forest Meteorology. 89.101-114.

Mahmood R. 1998. Air temperature variations and rice productivity in bangladesh. A comparative study of the performance of the yield and the ceres-rice models. Eco. Model.106.201-212.

Rosenzweig C and ML Parry. 1994. Potential impact of climate change on world food supply. Nature. 367.133-138.

Yao F, Y Xu, E Lin, M Yokozawa and J Zhang. 2007. Assessing the impacts of climate change on rice yields in the main rice areas of china. Clim. Chnge. 80.395-409.

Jones JW, G Hoogenboom, CH Porter, KJ Boote, WD Batchelor, LA Hunt, PW Wilkens, U Singh, AJ Gijsman and JT Ritchie. 2003. The dssat cropping system model. European Journal of Agronomy. 18.235-265.

Saltelli A. 2002. Sensitivity analysis for importance assessment. Risk Analysis. 22.579-590.

DeJonge KC, JC Ascough II, M Ahmadi, AA Andales and M Arabi. 2012. Global sensitivity and uncertainty analysis of a dynamic agroecosystem model under different irrigation treatments. Eco. Model.231.113-125.

Pathak H, J Timsina, E Humphreys and D Godwin. 2004. Simulation of rice crop performance and water and $\mathrm{n}$ dynamics, and methane emissions for rice in northwest india using ceres rice model. Technical Report. CSIRO Land and Water. 23.111.

Richardson CW and DA Wright. 1984. Wgen. A model for generating daily weather variables. Report ARS-8 August 1984. 83 p, 3 Fig, 12 Tab, 13 Ref, 4 App.

Evans J. 1993. Photosynthetic acclimation and nitrogen partitioning within a lucerne canopy. Ii. Stability through time and comparison with a theoretical optimum. Func. Plant Bio.20.6982.

Ritchie J, U Singh, D Godwin and W Bowen. 1998.Cereal growth, development and yield.In.Understanding options for agricultural production(Pp.79-98.

Quiring SM and DR Legates. 2008. Application of ceres-maize for within-season prediction of rainfed corn yields in delaware, USA. Agric. and For. Met.148.964-975.

Willmott CJ. 1982. Some comments on the evaluation of model performance. Bulltein of Amer. Met. Soc.63.1309-1369.

Buan RD, AR Maglinao, PP Evangelista and BG Pajuelas. 1996. Vulnerability of rice and corn to climate change in the philippines. Water, Air, \& Soil Pollution. 92.41-51. 
Amien I, P Rejekiningrum, A Pramudia and E Susanti. 1996. Effects of interannual climate variability and climate change on rice yield in java, indonesia. Water, Air, and Soil Pollution. 92.29-39.

Jin Z, D Ge, H Chen and J Fang. 1995. Effects of climate change on rice production and strategies for adaptation in southern china. Clim. Chng and Agric. 307-323.

Aggarwal PK and RK Mall. 2002. Climate change and rice yields in diverse agro-environments of india. Ii. Effect of uncertainties in scenarios and crop models on impact assessment. Climatic Change. 52.331-343.

Saseendran SA, KK Singh, LS Rathore, SV Singh and SK Sinha. 2000. Effects of climate change on rice production in the tropical humid climate of kerala, india. Climatic Change. 44.495514.

Seino H. 1995. Implications of climate change for crop production in japan. Clim. Chng and Agric. 293-306.

Peng S, J Huang, JE Sheehy, RC Laza, RM Visperas, X Zhong, GS Centeno, GS Khush and KG Cassman. 2004. Rice yields decline with higher night temperature from global warming. Proceedings of the National Academy of Sciences of the United States of America. 101.9971-9975.

Takuya W, FO Kumi and H Yuji. 1999. Effect of high air temperature and insufficient solar radiation during ripening period on the palatability and physiochemical properties of rice in 199 in kyushu region. Japanese J of Crop Sci.71.346-354.

Vijayalakshmi C, R Radhakrishnan, M Nagarajan and C Rajendran. 1991. Effect of solar radiation deficit on rice productivity. J of Agron. and Crop Sci.167.184-187.

Karim Z, M Ahmed, S Hussain and KB Rashid. 1994. Impact of climate change on the production of modern rice in bangladesh. Implications of Climate Change for International Agriculture Crop Modeling Study. 1-11.

Peart RM, JW Jones, RB Curry, K Boote and LH Allen. 1989.Impact of climate change on crop yield in the southeastern u.S.A.In.The potential effects of global climate change on the united states. (Dept of agricultural Research Service, Washington, DC.

Hendrey G and B Kimball. 1994. The face program. Agric. and For. Met.70.3-14. 